\title{
JUURNAL.RU
}

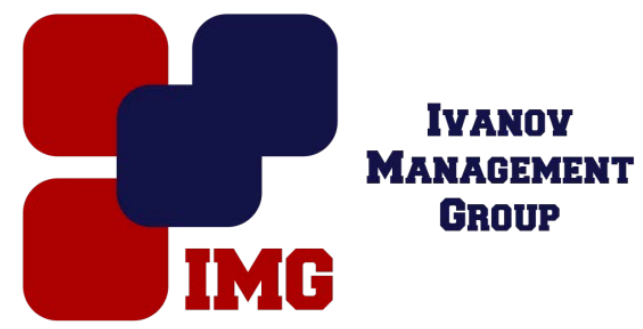

Соколюк С.И. Иркутский юридический институт (филиал) Академии Генеральной прокуратуры Российской Федерации Иркутск, Россия

doi: 10.18411/lj-30-11-2016-2-11

idsp 000001:lj-30-11-2016-2-11

\section{Коммуникация как неотъемлемая часть организации управления в сфере предоставления жилищно-коммунальных услуг}

\section{Аннотация}

В статье характеризуется сфера жилищно-коммунальных правоотношений как сложная структура межсубъектных связей в которой присутствует такой сегмент как коммуникация.

Ключевые слова: сфера жилищно-коммунальных правоотношений, коммуникация, услуги, ценности, управление.

Процесс предоставления жилищно-коммунальных услуг относится к ряду сложных правоотношений, сторонами которого выступают несколько субъектов. К таким субъектам следует отнести потребителя коммунальных услуг, исполнителя, выступающего в виде юридического лица либо индивидуального предпринимателя, ответственного за предоставление коммунальной услуги и ресурсоснабжающую организацию (далее по тексту - PCO), осуществляющую продажу коммунальных ресурсов.

Зачастую между рассматриваемыми субъектами происходят локальные конфликты, которые нередко приводят к предоставлению потребителю коммунальных услуг ненадлежащего качества или с перерывами, превышающими установленную законом продолжительность. Основой данных конфликтов, по нашему мнению, выступает нарушенная система правовых отношений, сложившаяся, в том числе, в результате срыва диалоговых мостов, отсутствия надлежащей коммуникации между участвующими в процессе предоставления жилищно-коммунальных услуг субъектами.

С точки зрения управления коммуникация является сложным социальным элементом и представляет собой процесс передачи и обмена информацией сообщающихся сторон: индивидов, социальных групп, организаций, государства и общества [3, С. 271]. Сам термин «коммуникация» происходит от латинского 
communicate, что означает «делать общим, связывать». Таким образом, основная цель коммуникации как таковой сводится к осуществлению взаимозависимых действий и решению совместных задач, которые, в свою очередь, способствуют сплоченности группы субъектов, приводят к снижению конфликтной напряженности между членами данной группы субъектов и обеспечивает взаимопомощь между ними.

Очевидно, что в процессе предоставления жилищно-коммунальных услуг, как и в других правоотношениях, подобного рода коммуникация осуществляется строго в рамках правового поля. Данное «общение» регулируется специфическим социальным регулятором, которым вступает право. В связи с этим рассмотрение вопроса об «отсутствии надлежащей коммуникации между субъектами» лишь в рамках экономических или психологических знаний не представляется возможным. Данный вопрос следует решать комплексно.

Следует отметить, что сфера жилищно-коммунальных услуг, равнозначно, как и сфера коммуникации, являются сферами комплексного правового регулирования, осуществляемого посредствам различных отраслевых юридических норм. Подавляющее большинство российских исследователей исходит из того, что отрасли права, а вместе с ними и институты права, следует выделять на основе двух критериев: предмета правового регулирования и метода правового регулирования, которые называются также основаниями деления норм права на институты и отрасли [4, С.14]. Предлагаемое обстоятельство, в свою очередь предполагает необходимость сравнивать различные объекты правового регулирования посредствам применения универсальных приемов исследования [5, С.14]. Одновременно, и жилищно-коммунальные отношения, и отношения коммуникации, являются разновидностями социальных ценностей [6, С.171]. Поэтому, в процессе исследования, очевидно, необходимо применять специальные аксиологические методы [7, С.346]. Помимо всего прочего, жилищно-коммунальные отношения, и отношения коммуникации представляя собой правовые категории, должны рассматриваться именно, как ценности в праве [8, С. 95]. В конечном счете, жилищно-коммунальные отношения, и отношения коммуникации предназначены для развития качества жизни людей [9, С. 71] и направленны на удовлетворение их нужд, интересов и потребностей [10, С. 263]. Данный аспект, предполагает изучение программ комплексного развития субъектов Российской Федерации [11, С. 13]. Ну и наконец, жилищнокоммунальные отношения, и отношения коммуникации, по нашему мнению, напрямую, либо косвенно, могут рассматриваться в качестве потенциально опасных объектов коррупционного посягательства [12, С. 27].

Рассматривая процесс предоставления коммунальных услуг как сложное и многогранное явление, а также, исходя из того, что коммуникативный процесс рождается на основе совместной деятельности отдельных групп субъектов, следует разобрать некоторые проблемы взаимоотношений в нескольких стадиях.

Так, первой стадией является стадия приобретения коммунальных ресурсов, где участниками выступают РСО и исполнитель, ответственный за 
предоставление коммунальной услуги потребителю. Заключение договора о приобретении коммунальных ресурсов - важное звено в цепи обеспечения потребителей жилищно-коммунальными услугами и является гарантом их качества. Однако, на практике не редки случаи, когда присутствуют явные нарушения данного договора. Так, например, отсутствует информация о механизме определения объема и качества поставляемого ресурса, механизме расчета стоимости коммунального ресурса с учетом действующего тарифа и иные условия, предусмотренные законодательством в сфере ресурсоснабжения. PCO для недопущения данных нарушений разрабатывает типовые договоры поставки коммунальных ресурсов, однако неисполнение данной обязанности ведет к тому, что как отправитель информации, РСО свои функции не исполняет, в связи, с чем на лицо срыв диалоговых мостов, и, как следствие, надлежащая коммуникация между указанной группой субъектов не осуществляется.

Стадия предоставления коммунальных услуг потребителю представляется второй стадией, в которой субъектами выступают исполнитель и потребитель коммунальной услуги.

В ситуации если рассматривать коммуникацию в узком смысле как процесс обмена информацией, то допускается привести пример - бездействия потребителя в виде непредставления информации по индивидуальным приборам учета для исполнителя. Где исполнитель в свою очередь не размещает информацию о предоставляемых им услугам и не обеспечивает свободный доступ к информации об осуществляемой ими деятельности. На лицо очевидная проблема - отсутствие двухстороннего обмена информацией.

Характеризуя сферу жилищно-коммунальных правоотношений как сложную структуру межсубъектных связей хотелось бы отметить, что в процессе коммуникации как PCO, так и исполнитель и потребитель коммунальных услуг должны быть связаны одной корпоративной стратегией, которая и будет определять главную цель их взаимоотношений предоставление коммунальных услуг надлежащего качества. А наложенная коммуникация между сторонами в любом случае облегчит их взаимодействие, обеспечит взаимопомощь и координацию в сложных социальных и правовых ситуациях. 


\section{Литература}

1. Прокурорский надзор за исполнением законов о тарифах в сфере жилищно-коммунального хозяйства: пособие / А.В. Паламарчук, С.Г. Хусяйнова, М.Ю. Кагамлык. - М., 2013. - 80 с.

2. Управление персоналом: учебник для бакалавров / под ред. А. А. Литвинюка. М.: Издательство Юрайт, 2011. - 433 с.

3. Управление персоналом: учебник и практикум для академического бакалавриата / В.М. Маслова. М.: Издательство Юрайт, 2015. - 492 с.

4. Муниципальное право России: учебное пособие / Под ред. А.В. Юрковского, - Изд-во Иркутского юридического института (филиала) Академии Генеральной прокуратуры РФ, 2014. - 341 с.

5. Юрковский А. В. Основные направления сравнительного правоведения // Вестник Санкт-Петербургского университета МВД России. 2016. № 2 (70). C. 55-59.

6. Юрковский А. В. Основные подходы к определению ценностей в правовой аксиологии // Синтез науки и общества в решении глобальных проблем современности. Сборник статей Международной научно-практической конференции. Уфа, 2016. С. 171-175.

7. Юрковский А. В. Аксиологические методы в сравнительном правоведении // Научный альманах - 2016. - N 2-3(16). - с. 340-346.

8. Юрковский А. В. Право как ценность и ценности в праве // Социология и право. - 2016. № 2 (32). - с. 95. - 102.

9. Юрковский А. В., Чигвинцев И. А. Прикладное применение конструкта «развитие» в правовой материи стран Северо-Восточной Азии и Российской Федерации: сравнительно-правовой анализ // Право и практика. - 2016. - № 2. - с. 64-71.

10. Юрковский А. В., Тугутова Д. А. Исследование правовой категории «интересы» во взаимосвязи с правовыми категории «нужда» и «потребность»: на примере Российской Федерации и государств СевероВосточной Азии // Современная научная мысль. - 2016. - № 2. - с. 254 264.

11. Арзуманов И.А., Личичан О.П. Программы комплексного развития территорий в Российской Федерации: правовое регулирование и практика реализации. Учебное пособие в 3 частях / Иркутский государственный университет, Юридический институт. Иркутск, 2016. Том Часть 2 Социально-экономическое развитие территорий как фактор стратегического планирования. - 193 с.

12. Довбня А.И., Юрковский А.В. Основные подходы к понятию коррупции // Вестник Барнаульского юридического института МВД России. 2016. № 1. (30). C. 27-28. 